\title{
Efektivitas Penggunaan Modul Berbasis Projeck Based Learning dalam Pembelajaran Teknologi Alat Berat
}

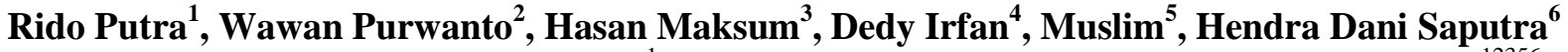 \\ Pascasarjana, Universitas Negeri Padang ${ }^{1}$, Jurusan Teknik Otomotif, Universitas Negeri Padang ${ }^{12356}$ \\ Jurusan Teknik Elektronika, Universitas Negeri Padang ${ }^{4}$ \\ Email: Ridoputera66@gmail.com¹,wawan5527@ft.unp.ac.id², hasan@ft.unp.ac.id ${ }^{3}$, \\ irfankumango@yahoo.com ${ }^{4}$, muslim@ft.unp.ac.id ${ }^{4}$, hendradani@t.unp.ac.id ${ }^{6}$ \\ DOI: http://dx.doi.org/10.31869/rtj.v5i1.2975
}

\begin{abstract}
Abstrak:Pembelajaran membutuhkan dukungan dari salah satu media yang handal, media tersebut salah satunya dapat berupa modul pembelajaran. Berdasarkan beberapa penelitian sebelumnya mengenai modul masih terdapat beberapa kekurangan dari modul yang diteliti. Sehingga dibutuhkan pengembangan lebih lanjut terhadap modul yang diberikan dengan menambahkan isi modul menggunakan proyek. Penelitian ini bertujuan mengkaji tentang pengembangan modul teknologi alat berat meliputi uji validitas, uji praktikalitas dan uji efektifitas berbasis proyek. Penelitian ini termasuk dalam penelitian Research and Development (R\&D). Model yang dipakai dalam penelitian ini menggunakan prinsip ADDIE, metode pengumpulan data melalui angket dan tes hasil belajar, analisis data diolah menggunakan pendekatan kuantitatif dan dideskripksikan melalui pendekatan kualititatif untuk meyimpulkan hasil penelitian, subjek penelitian terdiri dari dosen dan mahasiswa. Hasil penelitian yang dilakukan terhadap pengembangan modul berbasis $\mathrm{PjBl}$ memenuhi kelayakan, ditinjau dari aspek validitas, praktikalitas dan efektifitas. Hasil analisis aspek validitas adalah 89,07\% kriteria sangat valid, aspek praktikalitas rata-rata $87,92 \%$ kriteria sangat praktis. Aspek efektifitas dilihat dari tes pengetahuan dan tes proyek. Hasil tes pada 30 mahasiswa nilai skor rata-rata, sebesar 86,67\% kategori baik dan bidang keterampilan (proyek) sebesar 86,67\% kriteria sangat tinggi. Kesimpulan bahwa pengembangan modul berbasis $\mathrm{PjBL}$ mampu menarik perhatian dan membuat mahasiswa paham terhadap materi serta mampu bekerjasama dalam berkelompok
\end{abstract}

Kata Kunci: Modul, Projeck based learning (PjBL),Validitas, Praktikalitas, Efektifitas

Abstrack:Learning requires support from a reliable media, one of which can be a learning module. Based on several previous studies regarding the module, there are still some shortcomings from the module under study. So that further development of the given module is needed by adding the contents of the module using the project. This study aims to examine the development of heavy equipment technology modules including validity tests, practicality tests and project-based effectiveness tests. This research is included in Research and Development $(R \& D)$ research. The model used in this study uses the ADDIE principle, the data collection method is through questionnaires and learning outcomes tests, the data analysis is processed using a quantitative approach and described through a qualitative approach to conclude the research results, the research subjects consist of lecturers and students. The results of the research conducted on the development of PjBl-based modules meet the feasibility, in terms of aspects of validity, practicality and effectiveness. The results of the analysis of the validity aspect are $89.07 \%$ very valid criteria, the average practicality aspect is $87.92 \%$ very practical criteria. The effectiveness aspect is seen from the knowledge test and project test. The test results on 30 students have an average score of $86.67 \%$ in the good category and in the field of skills (projects) of $86.67 \%$ very high criteria. The conclusion is that the development of PjBL-based modules is able to attract attention and make students understand the material and be able to work together in groups

Keywords: Module, Project based learning (PjBL), Validity, Practicality, Effectiveness

\section{PENDAHULUAN}

Secara umum tujuan utama dari pendidikan kejuruan dan vokasi adalah mempersiapkan tenaga kerja yang terampil salah satunya melalui Technical and Vocational Education and Training (TVET)(Jama, 2018). Karakteristik dari TVET menekankan pada kemampuan pemecahan 
masalah, berpikir orde tinggi, mengkontsruksi pengetahuan sebelumnya(Abd Rashid, 2016), penerapannya bermuara pada pendidikan dan pelatihan(Hassan, Samsudin, \& Ismail, 2020). Perkembangan dunia kerja menuntut terbangunnya suatu masyarakat yang memiliki sistem sosial dan sistem budaya berbasis sains, teknologi dan rekayasa(Eliza Annis Thangaiah, Ruzzakiah Jenal, \& Jamaiah Yahaya, 2020). Menjawab reformasi sistem TVET tersebut dibutuhkanya antisipatif terhadap perubahan Abad XXI, maka pembelajaran disesuai dengan 21st Century Skills dan Creatif(Jama, 2018). Melalui suasana belajar dan pengajaran oleh dosen yang kreaktif merupakan faktor penting dalam meningkatkan kreativitas mahasiswa. Perangkat pengajaran yang bervasiasi berpengaruh pada suasana belajar seperti pembuatan modul mahasiswa, metode pengajaran, dan kelengkapan kelas(Badia \& Chumpitaz-Campos, 2018). Di sisi lain, kemampuan dosen dalam meningkatkan metode pengajaran juga memiliki pengaruh(Leaman \& Flanagan, 2013). Disarankan, seorang dosen harus dapat memfasilitasi mahasiswa dalam meningkatkan pembelajarannya(DeCuir-Gunby, Marshall, \& McCulloch, 2011), sehingga mereka mampu belajar baik saat menempuh pendidikan dan setelah lulus dari universitas. Kondisi ini membutuhkan dorongan baru dari pengajaran baru yang akan datang yang difokuskan pada pembelajaran student center yang menghubungkan dengan kehidupan nyata.

Mahasiswa harus dilibatkan dalam pembelajaran, sehingga mampu menanamkan sikap belajar sepanjang hayat. Dewasa ini, dalam menciptakan long life learning bagi mahasiswa, perlu memunculkan perspektif baru tentang pola pengajaran. Penelitian sebelumnya menyebutkan sebagai teori kognitif untuk pembelajaran guru untuk meningkatkan pengetahuan profesional(Anita Azmi, Rukun, \& Maksum, 2020), bagi dosen yang mahir mengelola kelas mampu meningkatkan berpikir kritis mahasiswa(Badia \& Chumpitaz-Campos, 2018). Selain itu, telah ada berbagai pandangan, pentingnya dosen mengintegrasikan beberapa model pengajaran(Bower, Dalgarno, Kennedy, Lee, \& Kenney, 2015) dan model sosialkonstruktivis untuk dosen dalam berkomunikasi dalam praktik mengajar(Dede,
Abdullah, Mulyanti, Rohendi, \& Sulaeman, 2020). Berdasarkan beberapa teori tersebut, suatu pelajaran tidak terfokus pada kebutuhan belajar siswa saat ini, tetapi harus terfokus pada pola kehidupan masa depan, sehingga siswa mampu menjadi pembelajar sepanjang hayatnya.

Dalam mendorong seorang mahasiswa, dosen perlu merancang dan mengelola pembelajaran dengan melibatkan mahasiswa secara luas. Lebih lanjut, Vogler et al., (2018) menjelaskan pentingnya pembelajaran yang dapat merangsang pengetahuan kognitif dan keterampilan psikomotorik(Vogler et al., 2018), kemudian pemecahan masalah dan kerja sama tim(Casner-Lotto, 2006). Menanggapi tuntutan tersebut Guo et al., (2020) mengemukakan proses pembelajaran yang menuntut siswa belajar secara aktif adalah PjBL(Guo, Saab, Post, \& Admiraal, 2020). Dalam Chen \& Yang (2019) dan Torres et al., (2019) mendefinisikan PjBL sebagai model yang menyelenggarakan pembelajaran berbasis proyek, pembelajaran kerja proyek(Chen, 2008)(Torres, Sriraman, \& Ortiz, 2019), dengan begitu kreativitas dan motivasi mahasiswa meningkat secara bertahap. Seiring dengan pandemi covid-19 saat ini, pembelajaran harus beralih ke kelas online (Maxim et al, 2021)(Grunis, Golovanova, Kirilova, Levina, \& Sizova, 2021), e-learning dan pembelajaran virtual menjadi solusi(Malkawi, Bawaneh, \& Bawa'aneh, 2021). Lebih lanjut, pada hakekatnya dalam proses pembelajaran pendidikan teknik dan kejuruan (TVET) siswa harus fokus pada keterampilan kognitif, tetapi kemampuan psikomotor dan afektif tidak boleh ditinggalkan(Hasanah, Sarwanto, \& Masykuri, 2018). Dengan kata lain, mereka harus terampil dengan sikap(Huang, 2020) dan pengetahuan yang baik(Monereo, Weise, \& Alvarez, 2013). Learning by doing merupakan ciri khas mahasiswa TVET(Anita Azmi et al., 2020). Oleh karena itu, model pengajaran kreatif dan perangkat pengajaran harus terintegrasi untuk mendukung keterampilan dan inovasi siswa TVET yang tinggi.

Modul adalah salah satu media pembelajaran yang bisa digunakan untuk menunjang kegiatan pendidikan dan pembelajaran. Konten dalam modul ini mencakup konten yang diperlukan untuk menguasai kemampuan. Sangat disarankan 
untuk mengembangkan kapasitas dalam satu modul, tetapi dengan mempertimbangkan karakteristik spesifik, luas dan kompleksitas kapasitas, dimungkinkan juga untuk mengembangkan kapasitas dalam beberapa modul. Ditambahkan oleh Prastowo (2011: 106) memberikan pendapat modul adalah bahan ajar yang disusun dalam sistem bahasa yang mudah dipahami peserta didik, sehingga mereka dapat belajar secara mandiri di bawah bimbingan minimal pendidik(Prastowo, 2016). Model pembelajaran berbasis proyek (PjBL) adalah pembelajaran aktif yang menghubungkan teknologi ke dalam kehidupan sehari-hari dengan melakukan kegiatan proyek dan menciptakan karya. Pendidik bertindak sebagai moderator dan evaluator produk buatan siswa dan memotivasi siswa melalui pembelajaran berbasis proyek. Modul pembelajaran berbasis proyek ini merupakan salah satu media pendukung tujuan dari TVET. Dalam modul pembelajaran berbasis PjBL, pembelajaran ditekankan pada ekosistem belajar peserta didik yang positif, kerja kelompok (kolaborasi), dan teknik evaluasi nyata (real evaluation). Pembelajaran didasarkan pada proyek objek, sedangkan dalam pembelajaran berbasis proyek, pembelajaran lebih didasarkan pada kegiatan desain; pekerjaan perumusan, desain (desain), perhitungan, pekerjaan pelaksanaan, dan hasil evaluasi. Pembelajaran berbasis proyek sangat cocok dipadukan dengan materi teknologi alat berat. Bentuk kegiatan pembelajaran kurikulum, materi alat berat menuntut siswa untuk aktif (student-centric) dalam berbagai eksperimen, seperti mengelompokkan berbagai eksperimen pembelajaran pada alat berat dan menguji karakteristik alat berat secara berkelompok. Percobaan materi teknologi alat berat. Selain itu, materi teknologi alat berat juga erat kaitannya dengan kehidupan seharihari, sehingga banyak kesempatan untuk mengajak siswa berpikir kritis dan kreatif tentang permasalahan nyata yang muncul dalam pembelajaran berbasis proyek. Dimana, definisi dari teknologi alat berat merupakan suatu mata kuliah pada jurusan otomotif yang ditempuh dalam 3 sks. Pembelajaran ini merupakan mata kuliah praktek dan teori yang mempunyai kompetensi antara lain yaitu: a) kompetensi Utama b) kompetensi Penunjang Teknis dan c) kompetensi Penunjang Teknis Soft skills.
Beberapa penelitian menggunakan model pembelajaran PjBL telah dilakukan oleh para peneliti sebelumya. Dilihat pada penelitian yang mengambarkan implemetasi pembelajaran berbasis proyek pada bidang kejuruan, dimana pembelajaran berbasis proyek menguntungkan dan efektif sebagai metode pembelajaran karena dibandingkan dengan metode pembelajaran yang lain, memiliki nilai tinggi dalam peningkatan derajat belajar mahasiswa.(Kejuruan, 2006). Dari penelitian tentang pengembangan modul dengan menggunakan model ADDIE. Hasil penelitian menunjukkan bahwa hasil verifikasi validator materi memberikan skor 2,9 untuk kategori baik, 3,6 untuk validator media untuk kategori sangat baik, 3,0 untuk validator pembelajaran untuk kategori baik, dan 3,8 untuk validator bahasa dalam kategori sangat baik (Hasanah et al., 2018). Dilanjutkan penelitian penggunaan modul dapat meningkatkan kreativitas belajar peserta didik, dengan keuntungan sebesar 0,46 atau berada pada kategori sedang (Novianto, Masykuri, \& Sukarmin, 2018). Selanjutnya, penelitian pengembangan keefektifan modul pembelajaran yang diperoleh dari nilai pre-test dan post-test setelah peserta didik menggunakan modul pembelajaran termasuk dalam kategori efektif(Marten \& Syah, 1858). Penelitian kajian PjBL pada kondisi sebelum dan sesudah pada saat pandemi covid-19 berlangsung dimana terjadinya peningkatan hasil belajar, motivasi, kemampuan berpikir kritis peserta didik(Malkawi et al., 2021). Penelitian sebelumnya tentang modul, hanya menggambarkan tentang pengembangan modul tetapi tidak mengkaji lebih dalam tentang penerapan modul dan pemakaian model PjBL. Modul tidak hanya digunakan sebagai bahan pembelajaran tetapi juga harus menekankan dari aspek afektif, kognitif dan menonjolkan psikomotor. Berdasarkan uraian masalah dan penelitian teoritis. Penelitian ini diarahkan kepada pengembangan modul dengan materi teknologi alat berat berbasis projek dengan melakukakan uji kevalidtan modul, kepraktisan penggunaan modul dan keefektifan penerapan modul dari aspek afektif, kognitif dan menonjolkan aspek psikomotor. Dimana dalam PjBL, pembelajaran terdiri dari lebih banyak kegiatan desain, pekerjaan perumusan, desain (layout), perhitungan, dan pengembangan 
pekerjaan dan evaluasi hasilnya. Jika model pembelajaran yang diterapkan sesuai dengan karakteristik mata kuliah, kondisi dan kebutuhan peserta didik didik, maka pembelajaran dapat lebih dioptimalkan

\section{METEDOLOGI PENELITIAN}

Penelitian ini termasuk dalam jenis penelitian $R \& D$. Menurut Borg and Gall (2003:569), langkah yang dapat menjelaskan semua kegiatan ketika mengembangkan produk saat ini atau menciptakan produk baru yang berbeda dari sebelumnya merupakan

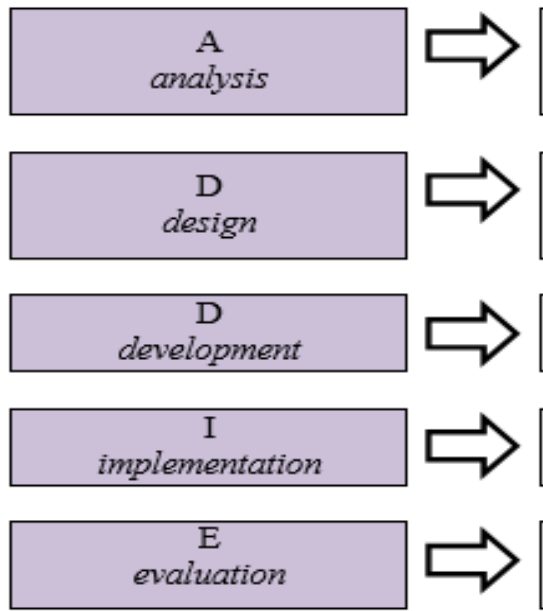

Menganalisaan kebutuhan pada masalah

dan solusi yang dirasa tepat serta untuk mengetahui kemampuan mahasiswa.

$\begin{aligned} & \text { Menentukan kemampuan } \\ & \text { metode, spesifik, } \\ & \text { pembelajaran. }\end{aligned}$
pembelajaran.

Membuat bahan ajar yang digunakan untuk program pembelajaran.

Melakukan rencana spesifikasi atau desain pembelajaran learning.

\section{Mengevaluasi rencana dan}

mengevaluasi hasil pembelajaran.

Gambar 1. Diagram Model ADDIE

Sumber: Pribadi (2009: 127)

Pada tahap ini, dilakukan uji validitas, uji praktikalitas dan uji efektifitas dimana pada uji validitas, kevalidan produk dilihat ketika instrument dapat menilai produk yang dikembangkan (Winatha, 2018). Pakar yang menilai produk haruslah pakar professional yang mengerti dengan produk yang dikembangkan, sehingga dapat menyampaikan kelemahan produk(Cahyadi, 2019). Selanjutnya pada uji Praktikalisasi dinilai untuk melihat bagaimana tingkat kepraktisan (kemudahaan penggunaan, biaya dan waktu yang terpakai) produk ketika dipakai oleh subjek penelitian. Tingkat kepraktisan di nilai melalui angket oleh dosen dan mahasiswa, yang akan dinilai pada angket diantaranya, dalam modul mempunyai komponen isi, komponen penyajian dan mempunyai manfaat. Kemudian, pada penelitian ini dilakukan uji efektifitas oleh mahasiswa terhadap modul pembelajaran dengan tujuan untuk melihat efek penggunaan modul pembelajaran diharapkan dapat mengoptimalkan hasil belajar mahasiswa. Untuk mengetahui efektifitas modul dilakukan dengan menggunakan instrumen hasil belajar. Sebelum pemberian produk dilakukan uji coba yang divalidasi dan diverivikasi oleh pakar yang ahli dibidangnya. Uji Coba produk berbasis $\mathrm{PjBL}$ dengan subjek uji coba dilakukan oleh dosen dan mahasiswa. Analisi uji coba produk dilakukan dengan pengisian angket respon dosen dan mahasiswa untuk modul yang dikembangkan.

Instrumen yang dipakai adalah angket evaluasi. Data angket evaluasi alat pembelajaran akan dievaluasi menggunakan skala Likert. Untuk analisis validitas peneliti menggunakan formula Aiken's dimana datadata yang didapat dari validator dimasukkan ke dalam formula sehingga diperoleh hasil kevalidan media yang sudah dikembangkan(Barseli, Ifdil, Mudjiran, Efendi, \& Zola, 2020). Data dari kepraktisan modul diperoleh dari angket untuk dosen dan angket untuk mahasiswa dalam kategori praktikalitas modul. Pada kisi-kisi kisi-kisi angket validasi materi, media dan bahasa dimana penilaian modul dilihat pada aspek kelayakan isi, kelayakan penyajian, kelayakan 
bahasa dan kelayakan kegrafikan dengan total jumlah 87 butir. Pada kisi-kisi kisi-kisi angket praktikalitas dosen dimana respon dosen dilihat dari aspek tampilan modul dan aspek penyajian materi dengan total 12 butir dan respon mahasiswa juga dilihat dari aspek tampilan modul, penyajian materi dan aspek manfaat dengan total 15 butir. Semua penilaian berbentuk Skala Linkert: sangat setuju (skor 4), setuju (skor 3), kurang setuju (skor 2), sangat tidak setuju (skor 1). Efektifitas diperoleh dengan menggunakan hasil belajar mahasiswa yang diperoleh dari jawaban soal yang sudah valid dan reliable hasil belajar mahasiswa kemudian digunakan sebagai bukti berhasilnya sebuah pembelajaran yang sudah dilaksanakan oleh mahasiswa. Tes hasil belajar mahasiswa bertujuan untuk memperoleh data didalam penguasaan materi yang disampaikan sesudah mahasiswa menggunakan modul pembelajaran berbasis proyek pada akhir tes untuk belajar. Tes praktik memiliki tujuan memperoleh data mengenai penguasaan materi keterampilan (proyek) yang diserahkan mahasiswa sesudah mengikuti pembelajaran menggunakan modul pembelajaran berbasis proyek, dan data tersebut dilakukan pada akhir tes.

Analisis efektifitas menggunakan desain one shot case study (Sugiyono, 2015: 435). Hasil penelitian diolah dengan menggunakan pendekatan kuantitatif yang dilakukan ketika menghitung penilaian yang bersifat kuantitatif dari penerapan modul pembelajaran berbasis $\mathrm{PjBL}$ tersebut, dan akan dideskripksikan dengan menggunakan pendekatan kualititatif untuk menyimpulkan hasil penelitian, hal ini bersumber dari penerapan pembelajaran secara berkala tetapi permasalahan pokok dalam penelitian ini adalah walaupun mahasiswa tersebut sudah pernah mempelajari materi tentang otomotif, tetapi mereka belum sepenuhnya mengerti akan hal materi yang akan dipelajari setelahnya. Maka peneliti langsung melakukan treatment tanpa melakukan tes terlebih dahulu. Peneliti melakukan post-test dengan 3 kali uji coba terbatas. Skor pretest dan posttest akan didapat dan dijadikan indikator tingkat keefektivan dalam pembelajaran yang biasa disebut dengan Gain score.

\section{PEMBAHASAN DAN ANALISA Hasil Penelitian}

Dalam penelitian ini, hasil tahap eksperimen dilakukan melalui eksperimen terbatas pada ahli materi, ahli media, ahli bahasa, dan 30 orang mahasiswa. Pengembangan modul pembelajaran berbasis proyek dikembangkan menurut model ADDIE. Pada tahap analysis (analisis) dilakukan analisis kebutuhan modul pembelajaran dan analisis karakteristik mahasiswa. Pada tahap design (desain) dilakukan perancangan modul pembelajaran meliputi mengumpulkan referensi, gambar-gambar yang relevan dengan materi pembelajaran teknologi alat berat pada mahasiswa tingkatan 3, dan menyusun instrumen penilaian modul pembelajaran. Pada tahap development (pengembangan) dilakukan pengembangan rancangan modul pembelajaran, penyuntingan modul pembelajaran, validasi, dan revisi. Tahap implementation (implementasi) yaitu pada saat modul pembelajaran dinyatakan layak oleh ahli materi dan ahli media serta ahli bahasa. Tahap terakhir adalah evaluation (evaluasi). Evaluasi yang dilakukan adalah dengan mengalisis data hasil penilaian modul pembelajaran oleh dosen ahli dan dosen teknologi alat berat.

Selanjutnya, dilakukan uji validitas, praktikalitas dan efektifitas modul. Dimana penilaian validitas modul dilakukan oleh 3 orang dosen ahli. Hasil penilaian untuk setiap aspek yang dinilai dalam modul dapat dilihat pada tabel berikut:

Tabel 1. Rata-rata Skor Hasil Penilaian Modul Oleh Ahli Materi

\begin{tabular}{ll}
\hline Aspek Kelayakan Modul & Rata-Rata \\
\hline Kelayakan isi & 90.00 \\
\hline Kelayakan Penyajian & 91.67 \\
\hline Kelayakan Kebahasaan & 88.46 \\
\hline Kelayakan Kegrafikan & 86.17 \\
\hline Jumlah & $\mathbf{3 5 6 . 3 0}$ \\
\hline Rata-rata & $\mathbf{8 9 . 0 7}$ \\
\hline
\end{tabular}

Selanjutnya, analisis kepraktisan

dilakukan untuk melihat kualitas kesesuaian 
praktis modul pembelajaran dengan tampilan dosen dan mahasiswa. dan penyajian materi yang dinilai dari respon

Tabel 2. Hasil Angket Respon Dosen pada Modul Pembelajaran

\begin{tabular}{lll}
\hline \multicolumn{1}{c}{ Aspek } & \multicolumn{2}{c}{ Persentase } \\
\hline Tampilan & 88,33 & \\
\hline Penyajian Materi & 87,50 & \\
\hline Rata-rata & $\mathbf{8 7 , 9 2}$ & \\
\hline
\end{tabular}

Angket respon mahasiswa juga digunakan ditinjau dari aspek tampilan, penyajian materi untuk menilai kepraktisan modul pembelajaran dan manfaatnya.

Tabel 3. Hasil Angket Respon Mahasiswa pada Modul Pembelajaran

\begin{tabular}{|c|c|}
\hline Aspek & Persentase \\
\hline Tampilan & 82,50 \\
\hline Penyajian Materi & 81,55 \\
\hline Manfaat & 82,08 \\
\hline Rata-rata & 82,04 \\
\hline
\end{tabular}

Selanjutnya dilakukan analisis efektifitas. keseluruhan dengan perhitungan one shot case Dimana, ditunjukan melalui diagram study sebagai berikut. perbandingan nilai mahasiswa secara

Tabel 4. Nilai Rata-rata Post-test dengan Perhitungan One Shot Case Study

\begin{tabular}{llll}
\hline \multicolumn{1}{c}{ Kegiatan } & $\mathrm{n}$ & \multicolumn{1}{c}{ Rata-rata } & \multicolumn{1}{c}{ Standar Deviasi } \\
\hline Post-test 1 & \multirow{3}{*}{30} & 74,22 & 6,55 \\
\cline { 3 - 4 } \cline { 3 - 4 } Post-test 2 & 77,89 & 6,28 \\
\cline { 3 - 4 } & & 82,33 & 9,56 \\
\hline
\end{tabular}

Berikut ini tampilan diagram hasil posttest dengan perhitungan one shot case study setelah diberi perlakuan dan mengalami peningkatan nilai rata-rata hasil belajar yang disajikan pada gambar berikut ini:

\section{Nilai Rata-rata}

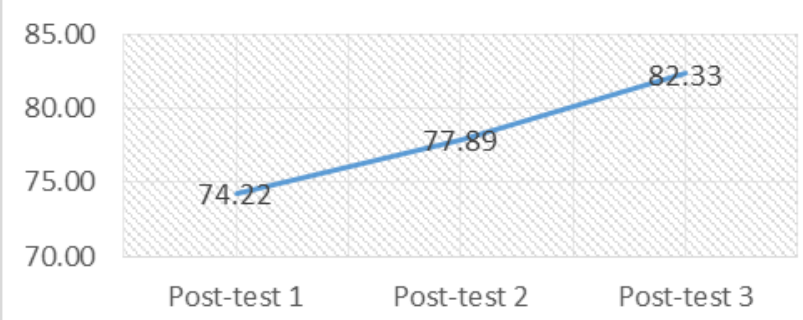

Gambar 2. Tampilan Diagram Hasil One Shot Case Study pada Pengujian Terbatas

Berdasarkan tabel 4 dan gambar 2 study mengalami kenaikan dari post-test 1 tersebut, terlihat bahwa nilai rata-rata post-test sampai ke post-test 3 . dengan menggunakan desain one shot case

Tabel 5. Data Hasil Rata-rata Nilai Post-test Pengujian Terbatas

\begin{tabular}{|c|c|c|c|c|c|}
\hline Kegiatan & $\mathrm{n}$ & Rata-rata & $\begin{array}{l}\text { Standar } \\
\text { Deviasi }\end{array}$ & $\begin{array}{l}\text { Nilai t } \\
\text { hitung }\end{array}$ & t-tabel \\
\hline Post-test 1 & 30 & 74,22 & 6,55 & \multirow{2}{*}{2,375} & \multirow{2}{*}{2,048} \\
\hline Post-test 2 & 30 & 77,89 & 6,28 & & \\
\hline Post-test 2 & 30 & 77,89 & 6,28 & \multirow{2}{*}{3,419} & \multirow{2}{*}{2,048} \\
\hline Post-test 3 & 30 & 82,33 & 9,56 & & \\
\hline Post-test 1 & 30 & 74,22 & 6,55 & 4,462 & 2,048 \\
\hline
\end{tabular}




\begin{tabular}{l|l|l|l|l|l}
\hline Post-test 3 & 30 & 82,33 & 9,56 & & \\
\hline \multicolumn{5}{|c|}{ adalah 82,56 . Selanjutnya data hasil analisis }
\end{tabular}

Dari hasil analisis tes akhir hasil belajar nilai belajar mahasiswa dapat dilihat pada tabel berikut:

diketahui bahwa rata-rata nilai tes hasil belajar

Tabel 6. Hasil Analisis Nilai Tes Belajar Mahasiswa

\begin{tabular}{lccccc}
\hline & $\mathrm{n}$ & $\begin{array}{c}\text { Nilai } \\
\text { Terendah }\end{array}$ & $\begin{array}{c}\text { Nilai } \\
\text { Tertinggi }\end{array}$ & $\begin{array}{c}\text { Rata- } \\
\text { rata }\end{array}$ & $\begin{array}{l}\text { Standar } \\
\text { Deviasi }\end{array}$ \\
\hline $\begin{array}{l}\text { Tes Hasil } \\
\begin{array}{l}\text { Belajar } \\
\text { Mahasiswa }\end{array}\end{array}$ & 30 & 56,67 & 93,33 & 82,23 & 9,56 \\
\hline
\end{tabular}

Persentase ketuntasan belajar klasikal kelas teknologi alat berat di jurusan teknik otomotif FT UNP pada pengujian terbatas

sebesar $86,67 \%$ dengan kriteria sangat tinggi. Selanjutnya data hasil analisis nilai proyek mahasiswa dapat dilihat pada tabel berikut: Tabel 7. Hasil Analisis Nilai Tes Proyek Mahasiswa

\begin{tabular}{lllcrl}
\hline & $\mathrm{n}$ & $\begin{array}{c}\text { Nilai } \\
\text { Terendah }\end{array}$ & $\begin{array}{c}\text { Nilai } \\
\text { Tertinggi }\end{array}$ & $\begin{array}{c}\text { Rata- } \\
\text { rata }\end{array}$ & $\begin{array}{c}\text { Standar } \\
\text { Deviasi }\end{array}$ \\
\hline $\begin{array}{l}\text { Tes Proyek } \\
\text { Mahasiswa }\end{array}$ & 30 & 70,28 & 85,74 & 80,50 & 4,47 \\
\hline
\end{tabular}

Persentase ketuntasan belajar klasikal kelas pada pengujian terbatas sebesar $86,67 \%$ pada bidang proyek (praktik) dengan hasil analisis tersebut diketahui bahwa ketuntasan belajar klasikal mencapai kriteria sangat tinggi pada persentase ketuntasan nilai hasil belajar kognitif dan nilai hasil belajar proyek (keterampilan), disimpulkan bahwa modul pembelajaran yang digunakan efektif.

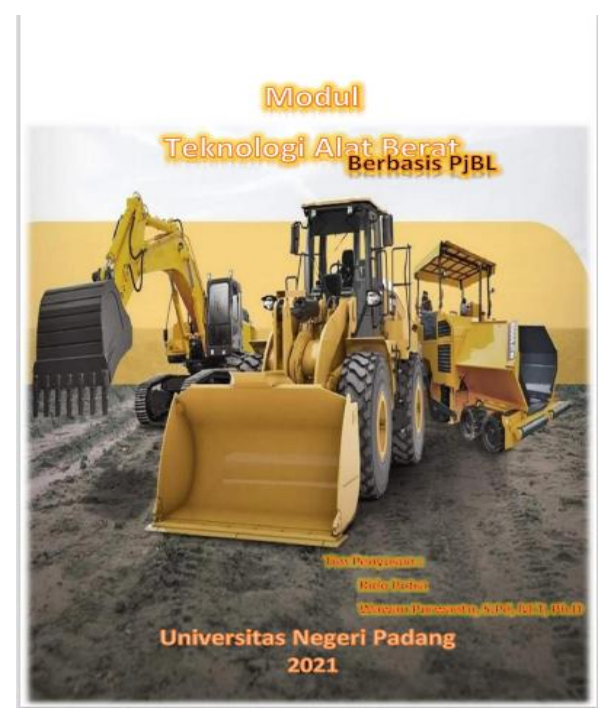

Gambar 3. Tampilan Halaman Sampul Modul

\section{Pembahasan Penelitian}

Dari tiga aspek penilaian modul pembelajaran di atas yaitu aspek validitas, aspek praktikalitas dan aspek efektifitas peneliti menyimpulkan bahwa modul pembelajaran berbasis $\mathrm{PjBL}$ yang dikembangkan sudah memenuhi kriteria valid, praktis dan efektif serta layak digunakan. Instrumen penilaian keefektifan diambil dari tes hasil belajar (aspek afektif dan kognitif) dan tes proyek mahasiswa(aspek psikomotor). Dimana pada modul sebelumnya hanya ditekankan kepada pengunaan modul sebagai bahan pembelajaran tetapi tidak menekankan kepada penerapan dari aspek afektif, kognitif dan kurang menonjolkan aspek psikomotor. Berdasarkan dari hasil penelitian, modul pembelajaran yang dihasilkan berkualitas memenuhi aspek validitas dengan kriteria valid dan persentase rata-rata skor validator adalah 89,07\%, dengan rincian aspek kelayakan isi persentase total adalah $90,00 \%$, aspek kelayakan penyajian $91,67 \%$, aspek kelayakan kebahasaan $88,46 \%$ dan aspek kegrafikan 86,17\%. Aspek praktikalitas terlihat dari hasil penilaian modul oleh dosen dan mahasiswa dengan lembar respon dosen dan mahasiswa. Penilaian modul pembelajaran menggunakan angket respon dosen mendapat skor persentase rata-rata $87,92 \%$ dengan kriteria sangat praktis. Penilaian modul pembelajaran dengan rincian aspek tampilan $88,33 \%$ dan aspek penyajian materi $87,50 \%$. Penilaian modul pembelajaran menggunakan angket respon mahasiswa mendapat skor persentase rata-rata $82,04 \%$ dengan kriteria sangat praktis. Penilaian modul pembelajaran dengan rincian aspek tampilan $82,50 \%$, aspek penyajian materi $81,55 \%$ dan aspek tampilan $82,08 \%$. Aspek efektifitas dilihat dari tes pengetahuan dan tes proyek. Hasil tes 
pengetahuan pada 30 mahasiswa dan tes proyek mendapatkan nilai skor rata-rata yang baik, namun masih ada 4 orang mahasiswa yang berada di bawah batas tuntas. Walaupun demikian, persentase ketuntasan belajar klasikal bidang pengetahuan sebesar $86,67 \%$ dan bidang keterampilan atau proyek matakuliah teknologi alat berat sebesar $86,67 \%$, sehingga berdasarkan tabel kriteria ketuntasan belajar klasikal diketahui bahwa ketuntasan belajar klasikal bidang pengetahuan dan keterampilan mencapai kriteria sangat tinggi, dapat disimpulkan bahwa modul pembelajaran yang digunakan efektif.

Penelitian pengembangan modul berbasis PjBL memberikan kontribusi sangat bagus untuk diterapkan ketika proses pembelajaran berlangsung, dapat dijadikan bahan pertimbangan dalam pelaksanaan proses pembelajaran pada matakuliah teknologi alat berat. Dosen juga dapat berkontribusi mengembangkan modul pembelajaran ini seiring dengan pandemi covid-19 sehingga penggunaannya tidak terbatas pada standar kompetensi yang peneliti kembangkan. Pembelajaran berbasis proyek masih terbatas karena aplikasinya masih baru mengakibatkan mahasiswa belum terbiasa dengan pembelajaran berbasis proyek, sehingga dibutuhkan waktu yang lebih lama pada awal pembelajaran. Terbatasnya waktu dalam mempresentasi hasil proyek yang sudah dilakukan mahasiswa. Pelaksanaan uji coba masih terbatas dan belum sampai melakukan uji coba secara luas. Disarankan, modul pembelajaran dapat diberikan terlebih dahulu kepada mahasiswa dalam bentuk softcopy sehingga mahasiswa dapat mempelajari terlebih dahulu tanpa membutuhkan danayang terlalu besar. Perlu adanya penelitian lebih lanjut mengenai modul pembelajaran berbasis PjBL pada matakuliah teknologi alat berat agar dapat membantu proses pembelajaran seiring dengan pandemi covid-19.

\section{PENUTUP}

Pengembangan modul pembelajaran berbasis PjBL ini mampu menarik perhatian mahasiswa dan membuat mahasiswa paham terhadap materi serta membuat mahasiswa mampu bekerjasama dalam berkelompok. Mahasiswa yang menggunakan modul berlandasan pembelajaran berbasis PjBL pada saat praktik, memiliki rasa lebih ingin tahu dengan segala informasi yang diterimanya dalam membantu menyelesaikan proyek atau tugas yang diberikan oleh dosen. Pengembangan modul pembelajaran berbasis PjBL juga dapat memperkaya dan menambah ilmu pengetahuan mahasiswa guna meningkatkan kualitas pembelajaran. Dampak lainnya dari pendekatan berbasis proyek ini adalah dalam proses pembelajaran mahasiswa cenderung lebih aktif untuk belajar dikarenakan kebiasaan dalam proses diskusi berkelompok, sehingga tujuan pembelajaran dapat tercapai nantinya.

\section{DAFAR PUSTAKA}

Abd Rashid, Z. (2016). Review of Web-Based Learning in TVET: History, Advantages and Disadvantages. International Journal of Vocational Education and Training Research, 2(2), 7. https://doi.org/10.11648/j.ijvetr.2016020 2.11

Anita Azmi, R., Rukun, K., \& Maksum, H. (2020). Analisis Kebutuhan Pengembangan Media Pembelajaran Berbasis Web Mata Pelajaran Administrasi Infrastruktur Jaringan. Jurnal Imiah Pendidikan Dan Pembelajaran, 4 (2), 303-314. Retrieved from

https://ejournal.undiksha.ac.id/index.php/ JIPP/article/view/25840/15852

Badia, A., \& Chumpitaz-Campos, L. (2018). Teachers learn about student learning assessment through a teacher education process. Studies in Educational Evaluation, 58(December 2017), 1-7. https://doi.org/10.1016/j.stueduc.2018.05 .004

Barseli, M., Ifdil, I., Mudjiran, M., Efendi, Z. M., \& Zola, N. (2020). Pengembangan modul bimbingan dan konseling untuk pengelolaan stres akademik siswa. Jurnal Konseling Dan Pendidikan, 8(2), 72. https://doi.org/10.29210/141700

Bower, M., Dalgarno, B., Kennedy, G. E., Lee, M. J. W., \& Kenney, J. (2015). Design and implementation factors in blended synchronous learning environments: Outcomes from a cross-case analysis. Computers and Education, 86, 1-17. https://doi.org/10.1016/j.compedu.2015.0 3.006

Cahyadi, R. A. H. (2019). Pengembangan 
Bahan Ajar Berbasis Addie Model. Halaqa: Islamic Education Journal, 3(1), 35-42.

https://doi.org/10.21070/halaqa.v3i1.212 4

Casner-Lotto, J. (2006). Are They Really Ready to Work? Human Resource Management, 1-64. Retrieved from https://files.eric.ed.gov/fulltext/ED51946 5.pdf

Chen, N. C. (2008). An educational approach to problem-based learning. Kaohsiung Journal of Medical Sciences, 24(3 SUPPL.), 23-30. https://doi.org/10.1016/S1607551X(08)70090-1

DeCuir-Gunby, J. T., Marshall, P. L., \& McCulloch, A. W. (2011). Developing and using a codebook for the analysis of interview data: An example from a professional development research project. Field Methods, 23(2), 136-155. https://doi.org/10.1177/1525822X103884 68

Dede, Abdullah, A. G., Mulyanti, B., Rohendi, D., \& Sulaeman. (2020). TVET learning innovation on automotive virtual laboratory based on cloud openstack. Journal of Technical Education and Training, 12(3 Special Issue), 51-60. https://doi.org/10.30880/jtet.2020.12.03.0 05

Eliza Annis Thangaiah, Ruzzakiah Jenal, \& Jamaiah Yahaya. (2020). Penerokaan Penggunaan E-Pembelajaran dalam Kalangan Pelajar dan Pengajar TVET Satu Kajian Awal. Akademika, 90(Isu Khas 3), 5-18. Retrieved from https://doi.org/10.17576/akad-202090IK3-01

Grunis, M. L., Golovanova, I. I., Kirilova, G. I., Levina, E. Y., \& Sizova, Z. M. (2021). Transformation of pedagogical communicative competence during creation digital online courses. Contemporary Educational Technology, 13(1), $1-13$. https://doi.org/10.30935/cedtech/9313

Guo, P., Saab, N., Post, L. S., \& Admiraal, W. (2020). A review of project-based learning in higher education: Student outcomes and measures. International Journal of Educational Research, 102(November 2019), 101586. https://doi.org/10.1016/j.ijer.2020.10158 6

Hasanah, I., Sarwanto, S., \& Masykuri, M. (2018). Pengembangan Modul Suhu dan Kalor Berbasis Project Based Learning untuk Meningkatkan Keterampilan Proses Sains dan Kemampuan Berpikir Kritis Siswa SMA/MA. Jurnal Pendidikan (Teori Dan Praktik), 3(1), 38. https://doi.org/10.26740/jp.v3n1.p38-44

Hassan, R., Samsudin, N. A., \& Ismail, A. (2020). Memperkasa TVET Malaysia melalui peranan MyRIVET - Berita UTHM. Retrieved from https://news.uthm.edu.my/ms/2020/09/m emperkasa-tvet-malaysia-melaluiperanan-myrivet/

Huang, C. E. (2020). Discovering the creative processes of students: Multi-way interactions among knowledge acquisition, sharing and learning environment. Journal of Hospitality, Leisure, Sport and Tourism Education, 26(August 2019), 100237. https://doi.org/10.1016/j.jhlste.2019.1002 37

Jama, J. (2018). Philosophy Tvet Di Era Derupsi. Jurnal Filsafat Indonesia, 1(3), 104-111.

Kejuruan, P. B. (2006). Implemetasi Pembelajaran Berbasis Proyek Pada Bidang Kejurua. Jurnal Cakrawala Pendidikan, 1(2). https://doi.org/10.21831/cp.v1i2.8515

Leaman, L. H., \& Flanagan, T. M. (2013). Authentic Role-playing as Situated Learning: Reframing teacher education methodology for higher-order thinking. Studying Teacher Education, 9(1), 4561.

https://doi.org/10.1080/17425964.2013.7 71573

Malkawi, E., Bawaneh, A. K., \& Bawa'aneh, M. S. (2021). Campus off, education on: Uaeu students' satisfaction and attitudes towards e-learning and virtual classes during covid-19 pandemic. Contemporary Educational Technology, 13(1), 1-14. https://doi.org/10.30935/cedtech/8708

Marten, D., \& Syah, N. (1858). Pesisir Selatan. 3.

Monereo, C., Weise, C., \& Alvarez, C. E. I. (2013). Changing university teacher's 
identity: Training based on dramatized incidents. Infancia y Aprendizaje, 36(3), 323-340.

https://doi.org/10.1174/02103701380753 3043

Novianto, N. K., Masykuri, M., \& Sukarmin, S. (2018). Pengembangan Modul Pembelajaran Fisika Berbasis Proyek (Project Based Learning) Pada Materi Fluida Statis Untuk Meningkatkan Kreativitas Belajar Siswa Kelas X Sma/ Ma. INKUIRI: Jurnal Pendidikan IPA, $7(1)$, https://doi.org/10.20961/inkuiri.v7i1.197 92

Prastowo, A. (2016). Perbaikan Mutu Pendidikan Melalui Pengembangan Bahan Ajar Mengacu Kurikulum 2013. Digilib.Mercubuana.Ac.Id.

Rohmah, F. (2020). Pengembangan Modul Sintaksis Bermodel Discovery Learning Untuk Mahasiswa Pendidikan Bahasa Indonesia. Jurnal Pendidikan Bahasa Dan Sastra, 20(1), 111-120. https://doi.org/10.17509/bs_jpbsp.v20i1. 25976

Sukardiyono, S., \& Rosana, D. (2017). Implementation of Integrated Science Instruction Assessment As an Alternative To Measure Science Process Skills and Social Attitudes. Journal of Science Education Research, 1(1). https://doi.org/10.21831/jser.v1i1.16185

Torres, A. S., Sriraman, V., \& Ortiz, A. M. (2019). Implementing Project Based Learning Pedagogy in Concrete Industry Project Management. International Journal of Construction Education and Research, 15(1), 62-79. https://doi.org/10.1080/15578771.2017.1 393475

Vogler, J. S., Thompson, P., Davis, D. W., Mayfield, B. E., Finley, P. M., \& Yasseri, D. (2018). The hard work of soft skills: augmenting the project-based learning experience with interdisciplinary teamwork. Instructional Science, 46(3), 457-488. https://doi.org/10.1007/s11251017-9438-9

Winatha, K. R. (2018). Pengembangan Emodul Interaktif Berbasis Proyek Mata Pelajaran Simulasi Digital. Jurnal Pendidikan Teknologi Dan Kejuruan, 15(2), https://doi.org/10.23887/jptk-

undiksha.v15i2.14021 